\title{
MANAJEMEN PROGRAM PRIVAT DIROSAH ISLAMIYAH DI PONDOK PESANTREN DAARUT TAUHIID BANDUNG
}

\author{
Akbar Ibrahim ${ }^{1}$, Sobar $^{2}$, Khambali $^{3}$ \\ 1,2,3 Program Studi Pendidikan Agama Islam, Universitas Islam Bandung \\ Jln. Ranggagading No. 8 Bandung \\ Email: 1akbaribrahim16@gmail.com,2Sobar@gmail.com \\ 3khambali1989@gmail.com
}

DOI: $10.29313 /$ tjpi.v7i1.3567

Accepted: March 12th, 2018. Approved: July 16th, 2018. Published: July 16th, 2018

\begin{abstract}
Private Program Dirosah Islamiyah is a program run by Pesantren Daarut Taubiid Bandung. This program is made for someone who has a solid activity and only has a little spare time, but still, wants to learn Islam. The purpose of this study is to know the management that includes the planning, implementation, and evaluation of the program. The approach in this study using qualitative with the descriptive method and data collection techniques with interviews, observation and documentation study. The results showed that: (1). Planning is done by bolding a Working Meeting in Daarut Tarbiyah Unit for determining how the program runs include the purpose of this program which is inseparable from the Vision and Mission of Pesantren Daarut Taubiid, and to share duties to each staff associated with their respective duties; (2). The implementation begins with the participants - the service of the congregation - the renbang team - the service of the congregation - the participants - the learning process, and the learning process is not the same as the learning process in general, where most of the initial activities, core activities and closing activities; and (3). Evaluation is done in the form of monitoring and report conducted by the renbang team to supervise related to existing activities and wider supervision done by the pesantren to the activity through a report from Daarut Tarbiyah.
\end{abstract}

Keywords: Management, Private Program, Dirosah Islamiyah.

\section{ABSTRAK}

Program Privat Dirosah Islamiyah merupakan program yang dikelola oleh Pesantren Daarut Taubiid Bandung. Program ini dibuat untuk seseorang yang memiliki aktivitas yang padat dan hanya memiliki waktu luang yang sedikit, tetapi tetap ingin mempelajari Islam. Tujuan dari penelitian ini adalah untuk mengetahui manajemen yang meliputi perencanaan, pelaksanaan dan evaluasi dari program tersebut. Adapun pendekatan dalam penelitian ini menggunakan kualitatif dengan metode desktiptif dan teknik pengumpulan data dengan wawancara, observasi dan studi dokumentasi. Hasil penelitian menunjukan bahwa: (1). Perencanaan yang dilakukan adalah dengan mengadakan Rapat kerja (RAKER) di Unit Daarut Tarbiyah untuk penetapan bagaimana program ini berjalan mencakup tujuan dari program ini yang tidak terlepas dari Visi dan Misi Pesantren Daarut Taubiid, serta membagikan tugas kepada setiap staf yang berhubungan dengan tugasnya masing-masing; (2). Pelaksanaannya dimulai dari peserta - pelayanan jamaah - tim renbang - pelayanan jamaah - peserta - Proses Pembelajaran, dan proses pembelajarannya pun tidak sama dengan proses pembelajaran pada umunya yang sebagian besar ada kegiatan awal, kegiatan inti dan kegiatan penutup; dan (3). Evaluasi dilakukan dalam bentuk pemantauan serta laporan yang dilakukan oleh tim renbang untuk mengawasi terkait dengan kegiatan yang ada dan pengawasan yang lebih luasnya dilakukan oleh pihak pesantren terhadap kegiatan melalui laporan dari Daarut Tarbiyah.

Kata Kunci: Manajemen, Program Privat, Dirosah Islamiyah. 


\section{PENDAHULUAN}

Pendidikan Agama merupakan pendidikan yang sangat penting dalam kehidupan seorang individu. Oleh karena itu, pendidikan agama wajib ada di setiap jenjang pendidikan formal maupun non formal.

Pendidikan Agama Islam adalah salah satu pendidikan yang sangat penting untuk dipelajari oleh manusia khususnya seorang muslim. Pendidikan Agama Islam meruapakan hal yang diajarkan oleh seorang pendidik terhadap anak didiknya dengan tujuan pengenalan ajaran-ajaran Agama Islam agar nantinya setelah selesai dari pendidikan itu ia dapat memahami, menghayati, dan mengamalkan ajaran agama Islam yang telah diyakininya secara menyeluruh dan menjadikan ajaran Agama Islam sebagai suatu pandangan hidupnya. Hal ini sesuai sebagaimana pendapat yang Abdul Majid (2012 : 12) jelaskan bahwa Pendidikan Agama Islam adalah: upaya sadar dan terencana dalam menyiapkan peserta didike untuk mengenal, memahami, menghayati, hingga mengimani, bertakwa dan berakblak mulia dalam mengamalkan ajaran agama Islam dari sumber utamanya kitab suci Al-Quran dan Al-Hadits, melalui kegiatan bimbingan, pembelajaran serta penggunaan pengalaman.

Pendidikan Islam pada dasarnya selain itu merupakan proses yang berlangsung terus menerus, pendidikan Islam berusaha untuk selalu mengembangkan serta membimbing fitrah serta segenap potensi yang dimiliki manusia. Fitrah dan potensi manusia yang dibimbing dan dikembangkan meliputi aspek jasmani maupun rohaninya. Bimbingan dan pengembangan tersebut bertujuan agar manusia mampu berperan dan mengabdi kepada Allah Swt, mengingat manusia berfungsi sebagai 'abid dan khalifatullah fil ardl. Oleh karena itu, pendidikan Islam pada hakekatnya mengarahkan dan mengembangkan manusia untuk bertaqwa kepada Allah Swt.

Manusia mempunyai kelebihan khas kemanusiaannya dibanding makhluk Allah
Swt yang lain, dimana manusia memiliki akal pikiran yang dapat dibudidayakan. Dengan pikiran manusia dapat mengembangkan eksistensinya untuk mampu memenuhi kebutuhan dalam mencari ilmu, terutama ilmu agama. Ilmu Agama menjadikan manusia semakin tebal imannya. Dengan demikian, manusia derajatnya dapat terangkat seperti yang dijanjikan oleh Allah Swt. dalam QS Al-Mujadallah ayat 11, yang berbunyi:

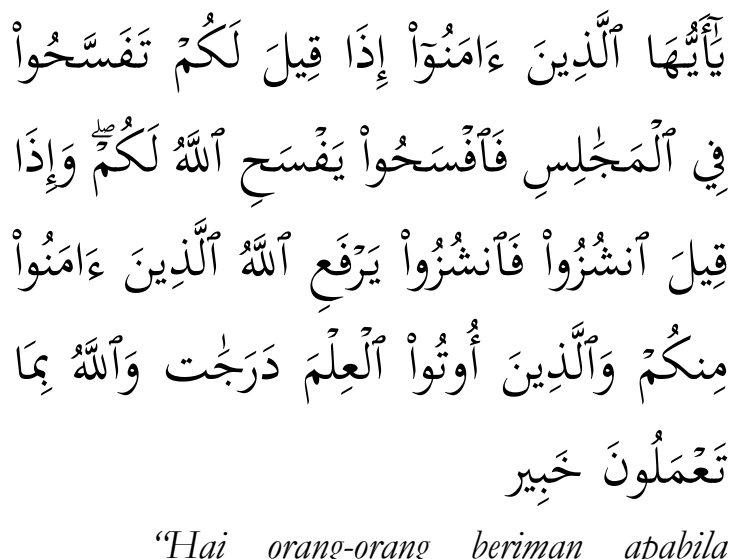
dikeatakan kepadamu: "Berlapang-lapanglah dalam majlis", maka lapangkanlah niscaya Allah akan memberi kelapangan untukmu. Dan apabila dikatakan: "Berdirilah kamu", maka berdirilah, niscaya Allah akan meninggikan orang-orang yang beriman di antaramu dan orang-orang yang diberi ilmu pengetabuan beberapa derajat. Dan Allab Maha Mengetabui apa yang kamu kerjakan" (Depag. RI, 2013: 543).

Bukti yang paling jelas yang menunjukkan bahwa secara fitrah manusia butuh terhadap agama adalah kenyataan bahwa semua bangsa mengenal kepercayaan terhadap dzat yang dianggap agung. Baik itu bangsa yang primitif maupun yang berperadaban, yang di Barat maupun yang di Timur, yang kuno maupun yang modern, serta dalam firman Allah dalam QS Ar-Rum ayat 30 :

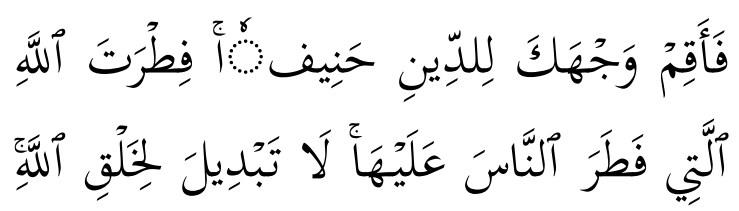




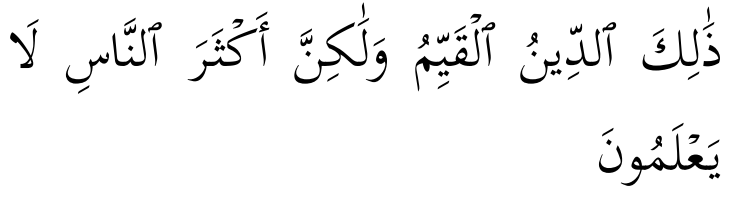

"Maka hadapkanlab wajahmu dengan lurus kepada agama Allab; (tetaplah atas) fitrah Allah yang telab menciptakan manusia menurut fitrah itu. Tidak ada peubahan pada fitrah Allab. (Itulah) agama yang lurus; tetapi kebanyakan manusia tidak mengetabui” (Depag. RI, 2013: 407).

Ayat di atas menjelaskan bahwasanya Allah telah menyeru kepada manusia agar tetap pada fitrahnya, yaitu beragama dan tetap menyembah Allah dan tetap berada di jalan yang lurus. Manusia diciptakan dengan fitrahnya yang baik, artinya manusia diciptakan dalam keadaan baik. Dan agamalah yang akan membuat seseorang istiqomah dalam kebaikannya. Hal ini Sebagaimana didefinisikan oleh para ahli bahwa agama adalah "tidak kacau" artinya seseorang yang dalam bimbingan agama hidupnya akan terarah. Dan agama yang paling diridhoi di sisi Allah adalah Islam. Oleh karena itu, pembelajaran agama Islam menjadi hal yang harus diprioritaskan bagi setiap manusia terutama seorang muslim.

Pentingnya pendidikan agama Islam bagi setiap muslim, menjadi dasar bahwa pendidikan agama Islam perlu dioptimalkan dan dilaksanakan dengan baik. Namun pada kenyataannya, tujuan dan idealisme pendidikan Islam tersebut sering kali mendapat banyak hambatan. Banyak di antara umat Islam sendiri yang tidak memahami ajarannya. Sehingga Akhir-akhir ini, rasa ingin tahu masyarakat akan pengetahuan tentang agama Islam sangat meningkat, akan tetapi terhambat oleh rutinitas kerja dan kesibukan yang membuatnya tidak bisa mempelajari Islam. $\mathrm{Hal}$ ini tentunya memerlukan perluasan sistem, yaitu menambah daya tampung sistem, sehingga sistem pendidikan Islam tidak hanya melayani anak-anak usia sekolah melalui pendidikan formal saja, melainkan melayani masyarakat melalui sistem pendidikan non-formal.
Berbagai Lembaga Pada lingkungan masyarakat sudah muncul untuk memenuhi permintaan akan pengetahuan agama, misalnya lembaga dakwah, kelompok pengajian, kuliah subuh, kajian-kajian Islami dan lain sebagainya. Ini semua dapat dipandang sebagai modal untuk mengembangkan sistem pendidikan nonformal. Artinya Orientasi sistem pendidikan Islam Indonesia telah mengalami perubahan dan perkembangan terus-menerus (Mastuhu, 1995 : 31). Akan tetapi sistem pendidikan agama Islam yang menggunakan metode halaqoh dan ceramah ini juga sering kali tidak mencapai tujuan idealnya, karena materi yang diajarkan disamaratakan padahal pengetahuan dan tingkat kefahaman yang dimiliki setiap orang berbeda. Artinya materi ajar mesti disesuaikan dengan kebutuhan masing-masing. Oleh kerena itu, perlu pengembangan sebuah program yang dapat mengatasi semua masalah masalah di atas demi tercapainya tujuan pendidikan Islam.

Contoh banyak orang yang kurang memahami atau bahkan sudah lupa mengenai Pendidikan Agama Islam yang sudah mereka pelajari di sekolah, dan ketika hal itu terjadi tidak mungkin mereka harus kembali ke sekolah yang sudah mereka lewati dulu karena terkendala adanya batasan umur. Contoh yang lain ketika seseorang suka mengikuti suatu kajian atau sering mengikuti majlis talim yang mana pesertanya tentu tidak perorangan melainkan berjamaah, tentu itu menjadi suatu kendala tersendiri karena setiap orang mempunyai persepsi, pemahaman serta kebutuhan yang berbedabeda, sedangkan suatu kajian atau majlis talim semua peserta akan sama rata menerima apa yang disampaikan oleh pemateri itu sendiri.

Privat istilah Dalam Kamus Besar Bahasa Indonesia mengandung arti Pribadi atau Tersendiri. Hukum privat adalah hukum yang mengatur hubungan antara sesama manusia, antar satu orang dengan orang yang lain dengan menitikberatkan pada kepentingan perorangan. Sedangkan Dirosah Islamiyah atau Studi Islam adalah 
usaha sadar dan sistematis untuk mengetahui dan memahami serta membahas secara mendalam tentang seluk-beluk atau hal-hal yang berhubungan dengan agama Islam, baik berhubungan dengan ajaran, sejarah maupun praktik-praktik pelaksanaannya secara nyata dalam kehidupan sehari-hari. Jadi dapat ditarik intinya bahwa Privat Dirosah Islamiyah adalah suatu usaha yang dibuat dan bertujuan agar seseorang yang mempunyai beberapa kendala pada saat ingin belajar Agama Islam atau kurang memahami mengenai Pendidikan Agama Islam bisa lebih paham dan memaknai Islam secara keseluruhan, serta pelaksanaannya pun dilakukan secara privat (pribadi) agar lebih kondusif dan tidak memakan waktu yang banyak.

Pondok Pesantren Daarut Tauhiid merupakan salah satu lembaga yang berperan aktif dalam meningkatkan mutu dari Pendidikan Agama Islam. Salah satunya Pesantren ini mempunyai program khusus yang dibuat untuk memudahkan setiap muslim dan muslimah dalam mempelajari Agama Islam dengan program yang dinamakan "Privat Dirosah Islamiyah". Program ini adalah salah satu program dari 3 unit yang ada di Pondok Pesantren Daarut Tauhiid, yaitu Daarut Tarbiyah.

Hasil wawancara dengan Angga, Yossi selaku pengurus dari unit Daarut Tarbiyah dan program Privat Dirosah Islamiyah di Pondok Pesantren Darut Tauhiid, bahwa yang dimaksud dengan Program Privat Dirosah Islamiyah adalah program pesantren non-mukim yang berdiri pada tahun 2007 yang dikhususkan bagi jamaah yang ingin belajar ilmu agama Islam, akan tetapi memiliki waktu yang singkat dan bersifat privasi. Jadi tujuan utama diadakan program ini adalah adanya kebutuhan masyarakat yang ingin lebih mempelajari mengenai Agama Islam tetapi tidak mempunyai waktu yang banyak karena rutinitas kerja atau kegiatan lainnya dan tidak bisa menginap serta untuk mem-fasilitasi adanya keinginan untuk belajar secara sendiri-sendiri atau khusus dan lebih privasi.
Program ini dilaksanakan secara satu "lawan" satu, atau satu guru satu siswa. Selain itu, proram Privat Dirosah Islamiyah ini sudah mempunyai lulusan sebanyak 185 orang peserta.

Privat Dirosah Islamiyah memiliki beberapa keunggulan dan tujuan sebagai berikut: 1) Memberikan pemahaman Islam yang benar kepada peserta, 2) Memotivasi peserta untuk melakukan ibadah ritual sesuai dengan Al-Qur'an dan Sunnah Rasulullah, 3) Mendorong muslimah untuk senantiasa mensucikan hati dan manajemen qolbu. Program ini sangat baik untuk para muslim dan muslimah yang ingin lebih mempelajari mengenai Agama Islam, tetapi mempunyai kendala seperti tidak menemukan waktu yang luang untuk mempelajari Studi Islam ini. Hal ini berkaitan dengan Manajemen Pendidikan, sehingga muncul pertanyaan: Bagaimana me-manage Program Privat Dirosah Islamiyah di Pondok Pesantren Daarut Tauhiid Bandung? Oleh karena itu, penting untuk diteliti guna mengetahui bagaimana cara Pesantren Daarut Tauhiid mengelola baik dari segi Perencanaan, Pelaksanaan, dan juga Evaluasi dari Program Privat Dirosah Islamiyah ini.

\section{PEMBAHASAN}

Proses dalam membuat atau menjalankan suatu program dibawah naungan lembaga/organisasi tertentu dibutuhkan suatu rangkaian kegiatankegiatan yang dapat membuat tujuan-tujuan yang telah ditetapkan sebelumnya dapat tercapai, yaitu Manajemen. Hal ini serupa dengan yang dijelaskan oleh Munir (2009: 9) bahwa manajemen adalah sebagai suatu proses yang diterapkan oleh individu atau kelompok dalam upaya-upaya koordinasi untuk mencapai suatu tujuan.

Suatu program apabila tujuan-tujuan yang ditentukan ingin tercapai, hendaknya penerapan fungsi Manajemen atau pengelolaan diterapkan di program tersebut (Perencanaan, Pengorganisasian, Pelaksanaan, Pengawasan). Sebagaimana 
yang diungkapkan oleh George R Terry (2000: 58), ia mengemukakan bahwa terdapat 4 fungsi utama dalam manajemen, yaitu POAC Planning (Perencanaan), Organizing (Pengorganisasian), Actuating (Penggerakan/Pelaksanaan), Controlling (Pengawasan).

\section{Perencanaan Program Privat Dirosah Islamiyah}

Penulisan dalam proses Perencanaan Program Privat Dirosah Islamiyah ini didalamnya mencakup proses perencanaan dan proses pengorganisasian. Pengumpulan data yang dilakukan mengenai perencanaan dan pengorganisasian program Privat Dirosah Islamiyah di Pondok Pesantren Daarut Tauhiid Bandung, penulis mendapatkan data dengan cara wawancara dan dokumentasi. Wawancara dilakukan dengan Mumuh Abdul Muhyi selaku Kepala Unit Daarut Tarbiyah di Pondok Pesantren Daarut Tauhiid Bandung. Wawancara dilaksanakan pada hari Senin tanggal 10 Juli 2017 yang bertempat di Kantor Daarut Tarbiyah.

Latar belakang diadakannya program Privat Dirosah Islamiyah di Pondok Pesantren Daarut tauhiid Bandung ini adalah karena banyaknya kebutuhan umat yang ingin belajar lebih mengenai Pendidikan Agama Islam tetapi mereka tidak mempunyai waktu yang banyak atau hanya bisa pada waktu-waktu tertentu saja dan juga tidak dengan sistem pembelajaran yang mengharuskan pesertanya harus menginap dikarenakan adanya kesibukan kerja atau kegiatan yang lainnya dan juga lebih memfasilitasi orang-orang yang ingin lebih belajar lebih secara personal (privasi).

Penyusunan perencanaan tentu saja yang menjadi tujuannya adalah terwujudnya visi dan misi dari Pesantren daarut Tauhiid itu sendiri dan tujuan-tujuan yang telah ditetapkan. Perencanaan Program Privat Dirosah Islamiyah mendandung beberapa hal yang harus dipersiapkan, diantaranya: (a) Ustadz/Pemateri, mencari ustadz dari kalangan sifitas Daarut Tauhiid serta para alumni Daarut Tauhiid yang memiliki pemahaman yang mendalam terhadap ilmu yang sesuai dengan kebutuhan peserta. Fiksasi ustadz terkait setuju atau tidaknya serta kesediaan mengajar sesuai dengan jadwal. H-1 ustadz konfirmasi kembali kepada tim renbang terkait bisa hadir atau tidaknya pada pertemuan yang akan dilakukan dengan peserta; (b) Peserta, peserta harus berumur 15-50 tahun, sehat jasmani dan rohmani, pendaftaran dilakukan di pelayanan jamaah Daarut Tarbiyah;

(c) Ruangan/Tempat Pelaksanaan, Menggunakan ruangan-ruangan yang ada di kawasan Pondok Pesantren Daarut Tauhiid Bandung, Masjid Daarut Tauhiid Bandung; (d) Pelayanan Jamaah, Pelayanan peserta yang akan mendaftar, Wawancara peserta yang akan mendaftar, meliputi keluhan, keinginan masalah-masalah atau ilmu yang ingin lebih diperdalam, Kesepakatan waktu pelaksanaan, pembayaran, Pengecekan tempat pelaksanaan dikarenakan tempatnya terbatas, dan Mengontak peserta terkait waktu pelaksanaannya setelah mendapat informasi bahwa peserta di acc dari tim renbang;

(e) Tim Renbang, Mem-proses datadata peserta yang masuk dari pelayanan jamaah, Menentukan acc/pending/tidak nya peserta untuk bisa mengikuti program Privat ini. Tetapi belum pernah ada yang sampai tidak di acc, kebanyakan hanya di pending karena keterbatasan dan ketersediaan pemateri/tempat. Mencarikan Pemateri yang siap dan sesuai dengan materi yang dibutuhkan oleh peserta. Mencari pemateri yang lain apabila pemateri yang telah sepakat sebelumnya berhalangan untuk hadir. Menyiapkan materi untuk 8 (Regular) dan 16 (mualaf) kali pertemuan yang sesuai dengan materi yang dibutuhkan oleh peserta; (f) Materi KBM, Aqidah, Akhlaq, Fiqih, AlQur'an, Tazkiyatun Nafs, Pengenalan Lembaga, Kebutuh Peserta; (g) Sarana Publikasi, Update info via Website, blog dan media sosial, Penyebaran/pemasangan 
brosur, pamphlet, leaflet ke masjid-masjid, Memaksimalkan jaringan dan alumni santri (Penyebaran brosur), Informasi program di agenda-agenda Masjid Daarut Tauhiid

Jika dalam fungsi perencanaan, tujuan dan rencana ditetapkan, maka dalam perorganisasian rencana tersebut diturunkan dalam sebuah pembagian kerja tertentu dalam sebuah struktur organisasi dimana didalamnya terdapat kejelasan bagaimana rencana organisasi akan dilaksanakan, dikoordinasikan, dan dikomunikasikan.

Terkait dengan pengorganisasian Program Privat Dirosah Islamiyah di Pondok Pesantren Daarut Tauhiid Bandung, telah terdapat struktur yang telah disesuaikan dengan kebutuhan, yaitu struktur dari Daarut Tarbiyah yang menangani seluruh programprogram yang ada di Daarut Tarbiyah itu sendiri. Pengorganisasian penting dilakukan agar pekerjaan yang dilakukan menjadi lebih efektif dan efisien, karena dengan adanya itu maka rencana-rencana yang telah ditentukan sebelumnya akan bisa terlaksana dengan sebagaimana mestinya.

Program privat Dirosah Islamiyah merupakan salah satu program yang dikelola oleh Daarut Tarbiyah. Dilihat dari gambaran struktur diatas bahwa pengorganisasian dari Daarut Tarbiyah ini sudah baik, tugas serta fungsi dari masing-masing unit pun sudah terjabarkan dengan jelas dari gambaran struktur organisasi diatas.

Daarut Tarbiyah selaku unit di Lembaga Pesantren Daarut Tauhiid yang menaungi program Privat Dirosah Islamiyah telah melaksanakan salah satu dari fungsi manajemen, yaitu Perencanaan. Perencanaan ini disusun sendiri oleh seluruh pihak yang terlibat dalam Unit Daarut Tarbiyah. Langkah pertama yang dilakukan adalah mengadakan rapat kerja dalam rangka membuat perencanaan Program Privat Dirosah Islamiyah, perencanaan ini dilakukan guna menetapkan segala sesuatu bagaimana proses program ini akan berjalan sebagaimana yang diharapkan termasuk penetapan tujuan dari program ini sendiri serta tidak terlepas dari Visi dan Misi dari Pondok Pesantren Daarut Tauhiid.

Pernyataan di atas sesuai dengan pengertian perencanaan yang mana George R Terry (2000:20) menjelaskan bahwa perencanaan adalah menentukan tujuantujuan yang hendak dicapai selama suatu masa yang akan datang dan apa yang harus diperbuat agar dapat mencapai tujuan-tujuan itu.

Perencanaan Program Privat Dirosah Islamiyah ini mengandung beberapa yang harus dipersiapkan oleh pihak-pihak yang terlibat didalamnya, diantara lain: (a) Ustadz, dari kalangan sivitas Pondok Pesantren Daarut Tauhiid atau dari kalangan alumni Daarut Tauhiid yang memiliki pemahaman yang mendalam tentang studi islam, harus memberikan kepastian bisa atau tidaknya memberikan materi kepada peserta Program Privat Dirosah Islamiyah; (b) Peserta, Berumur 15>50 tahun, sehat jasmani dan rohani, melakukan pendaftaran di Pelayanan Jamaah Daarut Tarbiyah; (c) Ruangan, Menggunakan ruangan-ruangan yang ada di kawasan Pondok Pesantren Daarut Tauhiid Bandung mencakup ruangan kelas, aula, Masjid Daarut Tauhiid; (d) Pelayanan Jamaah, Melayani peserta yang akan daftar, mewawancarai peserta terkait keinginan atau tujuan mengikuti Program Privat Dirosah Islamiyah, kesepakatan jadwal waktu pelaksanaan, pengecekan tempat pelaksanaan, mengontak peserta terkait waktu pelaksanaan; (e) Tim Renbang, Memproses data-data peserta yang telah masuk, menentukan lanjut atau tidaknya peserta dalam mengikuti Program Privat Dirosah Islamiyah, mencari pemateri yang sesuai dengan kebutuhan peserta, mencari pemateri apabila pemateri yang sebelumnya berhalangan hadir pada pertemuan dengan peserta, menyiapkan materi untuk peserta; ( $f$ ) Materi, Menentukan materi KBM Program Privat Dirosah Islamiyah meliputi (Aqidah, Akhlaq, Fiqih, Al-Qur'an, Tazkiyatun Nafs, Pengenalan Lembaga, Kebutuhan Peserta); dan (g) Sarana Publikasi, Update via sosial media, penyebaran brosur, pamphlet, 
memaksimalkan jaringan dan alumni santri, pemasangan spanduk, informasi programprogram disetiap agenda Masjid Daarut Tauhiid Bandung.

Pemaparan hasil temuan

Perencanaan Program Privat Dirosah Islamiyah di atas telah sesuai dengan beberapa Fungsi Manajemen yang diungkapkan oleh George R Terry (2000: 11) yang diantaranya: (a) Survey lingkungan; (b) Menentukan tujuan; (c) Evaluate, pertimbangan tindakan-tindakan yang diusulkan; dan (d) Communicate, berhubungan terus selama proses perencanaan.

Semua hal di atas menunjukan bahwa dalam menyusun suatu program khususnya Program Privat Dirosah Islamiyah di Pondok Pesantren Daarut Tauhiid ini memang sangatlah penting untuk menyusun Perencanaan terlebih dahulu agar seluruh target, tujuan serta harapan-harapan untuk Program Privat Dirosah ini dapat tercapai. Hal ini sesuai dengan yang dijelaskan oleh Nanang (2009: 49) bahwa merencanakan pada dasarnya menentukan kegiatan yang hendak dilakukan pada masa depan. Kegiatan ini dimaksudkan untuk mengatur berbagai sumber daya agar hasil yang dicapai sesuai dengan yang diharapkan.

Jika dalam fungsi Perencanaan Program Privat Dirosah Islamiyah tujuan dan rencana ditetapkan, maka dalam pengorganisasian ini rencana-rencana tersebut diturunkan dalam sebuah pembagian kerja tertentu dalam sebuah struktur organisasi yaitu Daarut Tarbiyah, dimana didalamnya terdapat kejelasan bagaimana rencana organisasi akan dilaksanakan, dikoordinasikan dan dikomunikasikan. Hal ini selaras dengan yang disampaikan oleh Nanang (2009: 71) bahwa pengorganisasian adalah proses membagi kerja ke dalam tugas-tugas yang lebih kecil, membebankan tugas-tugas itu kepada orang yang sesuai dengan kemampuannya, dan mengalokasikan sumber daya, serta mengkoordinasikannya dalam rangka efektivitas pencapaian tujuan organisasi.
Pengorganisasian dari Program Privat Dirosah Islamiyah di Pondok Pesantren Daarut Tauhiid Bandung ini telah terdapat struktur organisasi yang telah disesuaikan dengan kebutuhan, yaitu Struktur Organisasi dari Unit Daarut Tarbiyah yang menangani seluruh programprogram yang ada di unit itu sendiri. Pengorganisasian ini penting untuk dilakukan agar pekerjaan mengenai penetapan arah, tujuan, metode serta target capaian yang dilakukan sebelumnya bisa menjadi lebih efektif dan efisien. Karena dengan adanya pengorganisasian maka rencana-rencana di atas akan dapat terlaksana dengan sebagaimana mestinya.

Acuan beberapa fungsi manajemen yang diungkapkan oleh George R Terry (2000:11), adalah: (a) Identity, Tetapkan dengan teliti dan tentukan pekerjaan yang akan dilaksanakan; (b) Break Work Down, bagi-bagi pekerjaan menjadi tugas-tugas setiap orang; (c) Kelompok-kelompok posisi menjadi satuan-satuan yang dapat dipimpin dan saling berhubungan dengan baik; dan (d) Berhubungan selalu selama proses pengorganisasian. Maka, Pengorganisasian dalam Program Privat Dirosah Islamiyah di Pondok Pesantren Daarut Tauhiid Bandung sudah efektif. Hal tersebut terbukti dari adanya penetapan susunan organisasi yang disusun dengan terstruktur dan pengelompokkan komponen kerja kedalam struktur organisasi yang sudah teratur. Setiap unit dalam organisasi Daarut Tarbiyah telah mempunyai tugas, fungsi, wewenang, dan tanggung jawab masing-masing demi tercapainya tujuan yang telah ditetapkan sebelumnya.

\section{Pelaksanaan Program Privat Dirosah Islamiyah di Pondok Pesantren Daarut Tauhiid Bandung}

Hasil wawancara dan observasi menjadi dasar untuk memperoleh data dari narasumber selaku Kepala Unit Daarut tarbiyah yaitu Mumuh Abdul Muhyi. Berikut hasil yang penulis dapatkan mengenai Proses 
Pelaksanaan Program Privat Dirosah Islamiyah di Pondok Pesantren Daarut Tauhiid Bandung:

Proses Pelaksanaan Program Privat Dirosah Islamiyah di Pondok Pesantren Daarut Tauhiid ini, penulis memperoleh data dari hasil wawancara, observasi dan dokumentasi dari Kepala Bagian Operasional yaitu Dadang Subagja. Berikut uraian mengenai Pelaksanaan Program Privat Dirosah Islamiyah di Pondok Pesantren Daarut Tauhiid Bandung:

Pelaksanaan Program Privat Dirosah Islamiyah dilaksanakan dalam durasi 90 Menit setiap sesi/pertemuannya, dengan total 8 kali pertemuan untuk regular dan 16 kali pertemuan untuk mualaf dan juga setiap peserta dapat melakukan 3 sesi maksimal dalam 1 hari.

Tempat yang digunakan dalam Program Privat Dirosah ini di sekitar area Pondok Pesantren Daarut Tauhiid meliputi Masjid Daarut Tauhiid, aula, dan ruang kelas juga. Waktu Pelaksanaannya adalah setiap hari senin-jumat (Hari Kerja) pukul 08.0017.00 WIB (08.00-09.30, 10.00-11.30, 13.3015.00, 16.00-17.30). Dengan catatan Peserta/Santri bisa memilih sesi yang mana yang akan dipilih.

Alur yang terjadi saat Pelaksanaan Program Privat Dirosah Islamiyah dimulai dari awal pendaftaran sampai kepada pertemuan di pembelajaran: (a) Calon peserta/santri datang ke pelayanan jamaah untuk mendaftar Program Privat Dirosah Islamiyah; (b) Pengecekan jadwal privat yang sudah berjalan (karena tempat terbatas dan harus lebih privasi kondisi tempatnyapun); (c) Mengisi Formulir; (d) Peserta di wawancara (keluhan apa atau keinginan apa atau punya beberapa masalah seputar Islam atau ingin mendalami ilmu Agama Islam); (e) Penjadwalan dan Pembayaran; (f) Data dari peserta diberikan kepada Tim Renbang untuk diproses apakah akan langsung di acc atau di pending terlebih dahulu (karena keterbatasan pengajar dan tempat); (g) Apabila sudah di acc, tim renbang mencari materi yang sesuai dengan kebutuhan peserta/santri dan diolah untuk menjadi 8 pertemuan; (h) Tim renbang menghubungi pemateri yang memang mempuni untuk menyampaikan materi yang dibutuhkan oleh santri tadi; (i) Setelah proses diatas selesai semua dan pemateri sudah ada, maka proses kembali ke pelayanan jamaah untuk konfirmasi kepada peserta yang bersangkutan bahwa di telah di acc dan diminta untuk hadir pada pertemuan dengan waktu yang telah ditetapkan sebelumnya; (j) H-1 sebelum pertemuan, santri maupun pemateri harus mengkonfirmasi bahwa keduanya bisa hadir atau tidaknya pada pertemuan tersebut. Apabila pengajarnya tidak bisa hadir maka bagian pelayanan jamaah akan menghubungi tim renbang untuk mencari pemateri yang lain dan pertemuan akan tetap berlangsung, sedangkan apabila peserta yang berhalangan hadir maka akan dilangsungkan penjadwalan ulang, tetapi apabila konfirmasi tidak bisa hadir pada hari $\mathrm{H}$ maka pertemuan itu akan dianggap hangus atau akan dihitung telah melakukan 1 pertemuan; (k) Sebelum masuk pembelajaran, peserta akan diberikan modul selama Proses Program berjalan; (l) Pada awal pembelajaran akan ada kontrak belajar terlebih dahulu, dimana didalamnya akan ada penjelasan bagaimana proses pembelajaran berlangsung; (m) Materi yang diajarkan meliputi Aqidah, Akhlaq, Fiqih, Al-Qur'an, Urgensi Shalat, dan sesuai dengan kebutuhan peserta; dan (n) Proses pembelajaran selama $90 \mathrm{Menit} / \mathrm{sesi}$.

Alur Pelaksanaan di atas menjadi dasar untuk disimpulkan bahwa hampir seluruh pihak dari Struktur Organisasi ikut terlibat. Hal ini selaras dengan yang disampaikan oleh Sudjana (2010: 8) bahwa Penggerakan atau Pelaksanaan merupakan kegiatan untuk mewujudkan kinerja atau penampilan kerja sumber daya manusia dalam organisasi dalam melaksanakan program. Kegiatan ini diarahkan untuk terwujudnya organisasi yang menunjukan penampikan tugas dan partisipasi yang tinggi yang dilakukan oleh para pelaksananya. Produk fungsi penggerakan adalah 
bergeraknya organisasi dalam melaksanakan program sesuai dengan rencana. Dari pengertian tesebut dapat disimpulkan bahwa tercapai dan tidaknya suatu tujuan akan sangat bergantung kepada seluruh anggota yang ada, mulai dari tingkatan yang paling atas sampai yang paling bawah.

Tercapainya tujuan-tujuan dari Program Privat Dirosah Islamiyah bukan hanya tergantung pada Perencanaan dan Pengorganisasiannya saja, melainkan juga tergantung pada Pelaksanaan serta pengawasannya. Perencanaan dan Pengorganisasian hanyalah merupakan landasan yang kuat untuk adanya penggerakan yang terarah kepada sasaran yang dituju. Tetapi Penggerakan tanpa perencanaan pun tentu tidak akan berjalan efektif karena dalam perencanaan itulah ditentukan tujuan, budget, standar, metode kerja, prosedur dan program (Sukarna, 2011: 82-83).

Susunan Struktur Organisasi Daarut Tarbiyah mencakup Kepala dari Unit Daarut Tarbiyah yaitu Mumuh Abdul Muhyi, S.Ag.,M.Pd. Beliau sangatlah mengerti dalam tugasnya sebagai Ketua dari Daarut Tarbiyah serta sangat dominan dalam memonitor serta mengarahkan bawahan-bawahannya yang ada disusunan Struktur Organisasi Daarut Tarbiyah. Hal ini serupa dengan fungsi dan peranan dari Penggerakan atau Pelaksanaan (Actuating) adalah melakukan pengarahan, bimbingan dan komunikasi (Nawawi, 2009:95). Dengan kata lain peran pemimpin/Manajer sangatlah penting didalam fungsi manajemen penggerakan ini.

$$
\text { Proses Pelaksanaan dalam }
$$

Pembelajaran Program Privat Dirosah Islamiyah ini tidak sama dengan proses Pembelajaran pada umumnya yang hampir selalu terdapat kegiatan pendahuluan, kegiatan inti sampai kegiatan penutup. Alasannya karena program Privat Dirosah Islamiyah ini ini lebih bersifat privasi antara 1 guru dengan 1 muridnya maka isi pembelajarannya pun selain dari kebutuhan murid itu sendiri tetapi juga lebih kepada sharing tanpa ada urutan kegiatan pembelajaran sebagaimana pada umumnya.

Program Privat Dirosah Islamiyah ini bisa diartikan pula sebagai "ajang sharing" antara 1 guru dan 1 muridnya. Maka, pembawaan/penyampaian dari ustadz atau pemateri yang dicari oleh Tim renbang pun harus bisa membuat murid/santri bisa nyaman dan fokus dalam menjalankan program Privat Dirosah Islamyah ini. Hal ini serupa dengan 1 dari 4 komponen yang harus dikuasai oleh guru untuk menyelenggarakan pengajaran privat yang diungkapkan oleh J.J Hasibuan (1994:129), yaitu: Keterampilan mengadakan pendekatan secara pribadi, salah satu indikasi pengajaran atau pembelajaran Privat adalah terjalinnya hubungan yang akrab dan sehat antara guru dengan siswa.

Hal-hal di atas sesuai dengan yang diungkapkan oleh J.J Hasibuan (1994:130) yang mengemukakan beberapa Hubungan tatap muka antara guru dengan siswa secara perseorangan akan diwarnai oleh haikikat pengajaran perseorangan (Privat), diantaranya: (a) Hubungan interpersonal yang sehat serta akrab diantara guru dengan siswa; dan (b) Siswa mendapatkan bantuan dari guru sesuai dengan kebutuhan yang dibutuhkan oleh siswa tersebut.

\section{Proses Evaluasi Program Privat Dirosah Islamiyah di Pondok Pesantren Daarut Tauhiid Bandung}

Proses pengawasan atau evaluasi untuk Program Privat Dirosah Islamiyah ini tidak dapat diperoleh datanya secara lebih mendalam, karena memang data yang ada terkait evaluasi Program Privat Dirosah Islamiyah ini hanya untuk konsumsi internal saja dan tidak diberikan ke pihak lain.

Proses pengawasan atau evaluasi Program Privat Dirosah Islamiyah ini dilakukan dalam bentuk pemantauan serta pelaporan. Pengawasan dari intern sendiri dilakukan oleh Tim Renbang yaitu mengawasi terkait dengan penjadwalan kegiatan, pemateri dan lain sebagainya. 
Sedangkan pengawasan yang lebih luasnya dilakukan oleh pihak pesantren terhadap kegiatan Program Privat Dirosah Islamiyah, dengan melalui laporan-laporan yang dilakukan oleh Daarut Tarbiyah selaku Unit yang menangani Program tersebut.

Proses Pengawasan atau Evaluasi dari Program Privat Dirosah Islamiyah yang lain adalah Pengawasan jika terjadi penyimpangan-penyimpangan yang tidak sesuai dengan rencana dan tujuan awal yang telah ditetapkan sebelumnya. Pengawasan ini dilakukan oleh pimpinan Unit dari Daarut Tarbiyah yaitu Mumuh Abdul Muhyi terhadap staf staf yang ada dibawah naungannya.

Program Privat Dirosah Islamiyah ini tidak terdapat atau tidak menggunakan bentuk evaluasi seperti program-program lainnya seperti kuisioner atau angket atau hal lainnya. Faktor utamanya adalah karena program ini hanya memakan waktu yang sangat singkat dan pesertanya pun setiap pelaksanaannya hanya satu.

Adapun kendala-kendala yang dihadapi dalam Proses Penyelenggaran Program Privat Dirosah Islamiyah diantaranya: (a) Keterbatasan pemateri, karena banyak yang meminta jadwal di akhir pekan pihak tim renbang kesulitan mencari pemateri, berhubung kebanyakan pematerinya adalah dari pihak Internal Daarut Tauhiid itu sendiri; (b) Penyiapan sarana dan prasarana juga sering terlambat, karena tim yang sedang libur (Apabila privat dilaksanakan pada weekend); dan (c) Pemateri mendadak tidak dapat hadir, tim renbang harus mencari penggantinya dan tentu tidak mudah untuk mencari pemateri untuk penggantinya.

Proses Pengawasan atau Evaluasi dalam Program Privat Dirosah Islamiyah ini sebagian besar sudah berjalan. Proses ini dilakukan dengan maksud agar mengetahui tujuan-tujuan serta hal-hal lainya yang telah ditetapkan sebelumnya bisa terlaksana dengan baik.

Proses Pengawasan yang lain adalah Pengawasan jika terjadi penyimpangan- penyimpangan yang tidak sesuai dengan rencana dan tujuan awal yang telah ditetapkan sebelumnya. Pengawasan ini dilakukan oleh pimpinan Unit dari Daarut Tarbiyah yaitu Mumuh Abdul Muhyi terhadap staf staf yang ada dibawah naungannya.

Hal di atas sesuai dengan yang diungkapkan oleh Sukarna (2011: 110) yang mengemukakan bahwa Pengawasan dapat dirumuskan sebagai proses penentuan apa yang harus dicapai yaitu standard, apa yang sedang dilakukan yaitu pelaksanaan, menilai pelaksanaan, dan bilamana perlu melakukan perbaikan-perbaikan, sehingga pelaksanaan sesuai dengan rencana, yaitu selaras dengan standard (ukuran).

Proses yang dilakukan oleh Kepala Unit Daarut Tarbiyah pun yang selalu memonitor aktivitas keselurahan dari Program Privat Dirosah Islamoyahpun sudah selaras dengan Beberapa Fungsi Manajemen Pengawasan yang disampaikan oleh George R Terry (2000: 12) yaitu: (a) Tetapkan ukuran-ukuran; (b) Monitor hasilhasil dan bandingkan dengan ukuran-ukuran; (c) Perbaiki penyimpangan-penyimpangan; dan (d) Berhubungan selalu selama proses pengawasan.

Dengan demikian, Proses Pengawasan dalam hal apapun khususnya Program Privat Dirosah Islamiyah ini sangatlah penting karena dengan pengawasan ini seluruh hal-hal yang dipersiapkan dan direncanakan dari Proses paling awal akan berjalan dengan baik sebagaimana mestinya. Hal ini mengacu kepada pendapat dari Nanang (2009: 103) bahwa tujuan dari pengawasan adalah membantu mempertahankan hasil output yang sesuai dengan syarat-syarat sistem.

\section{KESIMPULAN}

Hasil penelitian dan pembahasan mengenai Manajemen Program Privat Dirosah Islamiyah di Pondok Pesantren Daarut Tauhiid Bandung, dapat disimpulkan sebagai berikut: 
(1) Perencanaan Program Privat Dirosah Islamiyah di Pondok Pesantren Daarut Tauhiid Bandung. Perencanaan yang dilakukan untuk menyelenggarakan Program Privat Dirosah Islamiyah ini adalah dengan mengadakan Rapat Kerja (RAKER) di Unit Daarut Tarbiyah yang isinya menetapkan segala sesuatu bagaimana proses program ini akan berjalan sebagaimana yang diharapkan termasuk penetapan tujuan dari program ini sendiri serta tidak terlepas dari Visi dan Misi dari Pondok Pesantren Daarut Tauhiid.

Menjabarkan satu per satu hal-hal yang diperlukan untuk bisa menyelenggarakan program ini. Lalu membagi tugas kepada setiap staf yang berhubungan dengan tugasnya masingmasing yang ada di struktur organisasi Daarut Tarbivah. Setelah Proses Perencanaan selesai maka diturunkan dalam sebuah pembagian kerja tertentu dalam sebuh struktur organisasi dimana didalamnya terdapat kejelasan bagaimana rencana organisasi akan dilaksanakan, dikoordinasikan, dan dikomunikasikan.

(2) Pelaksanaan Program Privat Dirosal Islamiyah di Podok Pesantren Daarut Tauhiid Bandung. Pelaksanaan Program Privat Dirosah Islamiyah ini menggunakan Metode sesuai nama programnya yaitu Privat (1 Guru 1 Murid). Materi yang diajarkan dalam Program ini meliputu Aqidah, Akhlaq, Fiqih, Al-Quran, Tazkiyatun nafs, Pengenalan Lembaga serta kebutuhan peserta. Proses Pelaksanaan dalam Pembelajaran Program Privat Dirosah Islamiyah ini tidak sama dengan proses Pembelajaran pada umumnya yang hampir selalu terdapat kegiatan pendahuluan, kegiatan inti sampai kegiatan penutup. Alasannya karena program Privat Dirosah Islamiyah ini ini lebih bersifat privasi antara 1 guru dengan 1 muridnya maka isi pembelajarannya pun selain dari kebutuhan murid itu sendiri tetapi juga lebih kepada sharing tanpa ada urutan kegiatan pembelajaran sebagaimana pada umumnya.

(3) Proses Evaluasi Program Privat

Dirosah Islamiyah di Pondok Pesantren
Daarut Tauhiid Bandung. Proses Pengawasan yang dilakukan sudah berjalan cukup baik. Hal ini dapat dilihat dari Proses pengawasan atau evaluasi Program Privat Dirosah Islamiyah ini dilakukan dalam bentuk pemantauan serta pelaporan. Pengawasan dari intern sendiri dilakukan oleh Tim Renbang yaitu mengawasi terkait dengan penjadwalan kegiatan, pemateri dan lain sebagainya. Sedangkan pengawasan yang lebih luasnya dilakukan oleh pihak pesantren terhadap kegiatan Program Privat Dirosah Islamiyah, dengan melalui laporan-laporan yang dilakukan oleh Daarut Tarbiyah selaku Unit yang menangani Program tersebut. Program Privat Dirosah Islamiyah ini tidak terdapat atau tidak menggunakan bentuk evaluasi seperti program-program lainnya seperti kuisioner atau angket atau hal lainnya. Faktor utamanya adalah karena program ini hanya memakan waktu yang sangat singkat dan pesertanya pun setiap pelaksanaannya hanya satu.

\section{DAFTAR PUSTAKA}

Depag. (2013). Al-Qur'anul-karim. Bandung: Khazanah.

Hasibuan, J, dkk. (1994). Proses Belajar Mengajar Keterampilan Dasar Pengajaran Mikro. Bandung: PT Remaja Rosdakarya.

Jultirasa, D dan Jhon Suprohanto. (1989). Manajemen Umum Sebuah Pengantar. Jakarta: PT Bulan Bintang.

Majid, A. (2012). Belajar dan Pembelajaran Pendidikan Agama Islam. Bandung: PT Remaja Rosdakarya.

Mastuhu. (1995). Dinamika Sistem Pendidikan Pesantren. Jakarta: INIS.

Nawawi, H. (2009). Manajemen Sumber Daya Manusia. Yogyakarta: Andi Offset.

Sudjana. (2010). Manajemen Program Pendidikan. Bandung: Falah.

Sukarna. (2011). Dasar-Dasar Manajemen. Bandung: Mandar Maju.

Terry, G. R dan Leslie W Rue. (2000). DasarDasar Manajemen. jakarta: Bumi Aksara. 
Akbar Ibrahim, Sobar, Khambali /_Ta’dib: Jurnal Pendidikan Islam, Vol. 7 No. 1 (2018) 398-409 